СТАТЬИ

УДК 632.7:631.8:633.36/.37:631.67

ЧИСЛЕННОСТЬ И ВРЕДОНОСНОСТЬ ФИТОФАГОВ ЭСПАРЦЕТА В ЗАВИСИМОСТИ ОТ АГРОХИМИЧЕСКИХ ФОНОВ И ПРЕДПОСЕВНОЙ ОБРАБОТКИ СЕМЯН БИШОФИТОМ

\author{
Земляницына С.В., Комарова О.П.
}

ФГБНУ «Всероссийский научно-исследовательский институт орошаемого земледелия», Волгоград, e-mail: komarova62@rambler.ru

В статье рассмотрены вопросы уточнения видового состава энтомофауны фитояруса и герпетобия в агроценозе эспарцета, используемого на зеленую массу в течение трех лет жизни, определено влияние различных агрохимических фонов и предпосевной обработки семян бишофитом на численность и вредоносность фитофагов фитояруса в условиях орошения. Установлено, что в энтомоценоз эспарцета входит 875 видов насекомых, в числе которых 387 видов фитофагов. Наиболее многочисленными в энтомокомплексе эспарцета в Нижнем Поволжье являются представители отрядов Coleoptera и Hymenoptera (29,0 и 28,9\% от общего числа видов). Среди фитофагов отмечены как многоядные, так и специализированные виды. Периодически эспарцету наносят серьезные повреждения полифаги: луговой мотылек, люцерновая и хлопковая совки, медведка обыкновенная, личинки щелкунов и чернотелок и др. Из олигофагов вредят листовой люцерновый долгоносик, различные виды клубеньковых долгоносиков, люцерновый клоп. Наиболее многочисленными энтомофагами герпетобия являются жужелицы - 78 видов. Среди энтомофагов, обитающих в травостое эспарцета, наиболее многочисленны и активны хищные клопы - Nabis spp., Orius spp., хищные трипсы, жуки и личинки семейства Coccinellidae. Из паразитических перепончатокрылых зарегистрированы представители семейств Ichneumonidae, Pteromalidae, Tetrastichidae, Scelionidae. Дана оценка изменения численности фитофагов под воздействием удобрений и предпосевной обработки семян эспарцета песчаного бишофитом в условиях орошения. Показано, что применение минеральных и органических удобрений на посевах эспарцета в сравнении с контролем (без применения удобрений) во всех случаях способствует достоверному снижению численности вредителей на посевах второго и третьего лет жизни эспарцета в орошаемых условиях. Установлено, что обработка семян эспарцета бишофитом оказала сдерживающее влияние на численность всех изучаемых видов фитофагов, снижение численности вредителей при применении бишофита составило от 28,5 до $58 \%$ на посевах второго и третьего лет жизни.

Ключевые слова: эспарцет, фитофаги, энтомофаги, орошение, агрохимический фон, бишофит

\title{
NUMBER AND HARMFULNESS OF SAINFOIN PHYTOPHAGES DEPENDING ON AGROCHEMICAL BACKGROUNDS AND PRE-SOWING SEED TREATMENT BY BISHOPHITE
}

\author{
Zemlyanitsyna S.V., Komarova O.P.
}

All-Russian Research Institute of Irrigated Agriculture,Volgograd, e-mail: komarova62@rambler.ru

\begin{abstract}
The article considers the issues of clarifying the species composition of entomofauna of phytotier and herpetobium in sainfoin agrocenosis, used on green mass during three years of life, determined the influence of various agrochemical backgrounds and pre-treatment of seeds with bischofite on the number and harmfulness of phytophages of phytotier in irrigation conditions. It has been established that sainfoin entomocenosis includes 875 species of insects, including 387 species of phytophages. The most numerous in the sainfoin entomocomplex in the Lower Volga region are representatives of the orders Coleoptera and Hymenoptera (29.0 and $28.9 \%$ of the total number of species). Among phytophages, both multi-species and specialized species are noted. Periodically, sainfoin are seriously damaged by polyphages: meadow moth, alfalfa and cotton scoops, common bear, larvae of elaterid and darkling beetles, etc. Leaf alfalfa weevil, various types of sitona, alfalfa plant bug harm from oligophages. The most numerous entomophages of herpetobium are representatives of the Carabidae family -78 species. Among the entomophages living in the sainfoin herb, the most numerous and active predatory bugs are Nabis spp., Orius spp., predatory thrips, beetles and larvae of the Coccinellidae family. Representatives of the families Ichneumonidae, Pteromalidae, Tetrastichidae, Scelionidae are registered from parasitic-hymenoptera. An estimate of the change in the number of phytophages under the influence of fertilizers and pre-treatment of sainfoin seeds with bischofite in irrigation conditions is given. It has been shown that the use of mineral and organic fertilizers on sainfoin in comparison with control (without the use of fertilizers) in all cases contributes to a reliable reduction in the number of pests on crops of the second and third years of sainfoin life under irrigated conditions. It was found that the treatment of sainfoin seeds with bischofite had a restraining effect on the number of all studied species of phytophages, the decrease in the number of phytophages using bischofite ranged from 28.5 to $58 \%$ on crops of the second and third years of life.
\end{abstract}

Keywords: sainfoin, phytophages, entomophages, irrigation, agrochemical background, bischofite

Обеспечение животноводства растительным кормовым белком за счет расширения площадей возделывания и повышения урожайности многолетних бобовых трав - общемировая проблема $[1,2]$. Одной из ключевых задач, поставленных перед агропромышленным комплексом России, является производство высокобелковых 
кормов. В решении этой задачи главная роль принадлежит многолетним травам, в частности эспарцету. Эспарцет является перспективной высокобелковой кормовой культурой для кормопроизводства страны. Эспарцет отличается также высоким содержанием жирных масел, аскорбиновой кислоты, безазотистых экстрактивных веществ и незаменимых аминокислот [3, 4]. Хозяйственная значимость эспарцета не исчерпывается его высокой питательной ценностью. Эта культура ценна также его способностью повышать содержание в почве азота за счет его фиксации симбиотическими бактериями. По данным С.А. Игнатьева и А.А. Регидина, эспарцет в различных почвенно-климатических зонах способен накапливать от 100 до180 кг/га биологического азота, это прекрасный предшественник. Его также можно использовать и в качестве сидерата, что позволяет снизить количество минеральных удобрений при выращивании последующих культур [1].

Это особенно важно для условий орошаемого земледелия, поскольку при орошении особо острой является проблема восстановления и поддержания на высоком уровне плодородия почв, как основы получения стабильных урожаев сельскохозяйственных культур.

Среди резервов повышения урожайности эспарцета одними из важнейших являются вопросы научно обоснованной защиты его от вредителей. Поражение комплексом фитофагов в значительной степени (от 30 до 50\%) снижает продуктивность эспарцета и качество корма [5-7]. В связи с этим проблема защиты посевов эспарцета от патогенов в технологии возделывания этой культуры становится одной из наиболее актуальных.

Цель исследования: изучить видовой состав энтомокомплекса эспарцета песчаного в Нижнем Поволжье, определить влияние различных агрохимических фонов и предпосевной обработки семян бишофитом на численность и вредоносность фитофагов в орошаемых условиях.

\section{Материалы и методы исследования}

Исследования проводились нами в 2004-2016 гг. на посевах эспарцета в ФГУП «Орошаемое» ФГБНУ ВНИИОЗ (г. Волгоград). Климат региона резко континентальный, засушливый. Почвы региона исследований светло-каштановые, по механическому составу - тяжелосуглинистые. Способ орошения - дождевание (ДМ Мини
Кубань - К) при поддержании предполивной влажности почвы не ниже 70-75\% НB.

Изучение видового состава энтомофауны эспарцета, численности и вредоносности фитофагов проводили в полевых двухфакторных опытах. Первый фактор - 5 вариантов агрохимических фонов: контроль (без внесения удобрений); $\mathrm{N}_{30} \mathrm{P}_{90} \mathrm{~K}_{70}+\mathrm{N}_{100}$ (в подкормку); сидерат $20 \mathrm{~T} /$ га $+\mathrm{P}_{30} ;$ солома $6 \mathrm{~T} / г \mathrm{a}+\mathrm{N}_{60}$ и навоз в дозе $60 \mathrm{~T} /$ га. Второй фактор - предпосевная обработка семян бишофитом и контроль (без обработки).

Учеты насекомых проводили еженедельно на посевах эспарцета первого-третьего лет жизни в течение вегетационного сезона: насекомых фитояруса учитывали методом кошения энтомологическим сачком со съемными мешочками с пересчетом численности насекомых на $1 \mathrm{~m}^{2}$, герпетофауну - почвенными ловушками Барбера $[8,9]$.

Статистическую обработку результатов проводили с использованием программы Microsoft Office Excel.

\section{Результаты исследования и их обсуждение}

За годы исследований (2004-2016 гг.) на посевах эспарцета нами было собрано более 93 тыс. экземпляров различных видов насекомых, относящихся к 875 видам, из которых 387 видов - фитофаги.

В энтомокомплексе эспарцета в Нижнем Поволжье наиболее многочисленны по количеству видов отряды Coleoptera и Hymenoptera - соответственно 29,0 и 28,9\% от общего числа видов. Большое количество видов принадлежит к отрядам Diptera и Orthoptera (16,4 и 12,2\% видов). На долю остальных семи отрядов (Manteoptera, Dermaptera, Homoptera, Hemiptera, Thysanoptera, Lepidoptera, Neuroptera) в агроценозе эспарцета приходится суммарно 13,5\% видов (рисунок).

Посевы эспарцета подвергаются нападению довольно большого комплекса вредителей, среди которых имеются как многоядные, так и специализированные виды. Такие многоядные виды, как луговой мотылек (Loxostege sticticalis L.), люцерновая (Heliothis viriplaca Hfn.) и хлопковая (Helicoverpa armigera Hbn.) совки, наносят весьма существенный вред этой культуре. Заметно вредят также медведка обыкновенная (Gryllotalpa gryllotalpa L.), личинки щелкунов и чернотелок (сем. Elateridae и Tenebrionidae), личинки ростковых мух (Delia spp.) и другие почвообитающие вредители, по- 
вреждающие подземные и прикорневые части растений. Периодически эспарцету наносят серьезные повреждения саранчовые насекомые (сем. Acrididae), свекловичные долгоносики (Asproparthenis punctiventris Germar, Tanymecus spp.), свекловичный клоп (Poeciloscytus cognatus Fieb.) и др.

Из олигофагов наиболее серьезными являются листовой люцерновый долгоносик (Hypera postica Gyll.), повреждающий листья, различные виды клубеньковых долгоносиков (Sitona spp.), жуки которых объедают листья, а личинки питаются на корнях. Корни эспарцета повреждаются личинками большого люцернового долгоносика (Otiorhynchys ligustici L.). Также вредоносны люцерновый клоп (Adelphocoris lineolatus Goeze.), полевые клопы (Lygus spp.), гороховая тля (Acyrthosiphon pisum Harris.).

Из энтомофагов, обитающих в травостое эспарцета, к наиболее многочисленным и активным можно отнести хищных клопов - набисов и ориусов (Nabis ferus L., Orius niger Wolff.), хищного трипса (Thrips spp.), жуков и личинок тлевых коровок (сем. Coccinellidae). В травостое эспарцета отмечены также имаго перепончатокрылых из семейств Ichneumonidae, Pteromalidae, Tetrastichidae, Scelionidae. Среди энтомофагов напочвенного яруса доминируют жужелицы (Carabidae), 78 видов которых зарегистрировано на посевах эспарцета. В своем большинстве жужелицы являются активными хищниками $[10,11]$. Наиболее многочисленны среди жужелиц Calosoma auropunc- tatum Hbst., Poecilus cupreus L., P. sericeus F.-W., Pseudoophonus rufipes L., Harpalus distinguendus Duft. В сборах почвенными ловушками эти виды составили 72$75 \%$. Доминантные виды родов Calosoma и Poecilus по характеру питания являются активными хищниками, а для представителей Pseudoophonus spp. и Harpalus spp. характерно смешанное питание.

В наших исследованиях дана оценка влияния различных агрохимических фонов и предпосевной обработки семян эспарцета бишофитом на численность и вредоносность основных видов фитофагов в условиях орошения. В литературе отмечается, что научно обоснованное применение минеральных и органических удобрений не только оказывает положительное влияние на рост и развитие растений эспарцета, но и повышает их устойчивость к комплексу фитофагов $[12,13]$. Особенно важна в регулировании численности вредителей подкормка посевов минеральными удобрениями. Исследованиями А.Е. Прокопчука установлено, что сбалансированное внесение минеральных удобрений приводит к развитию более мощной корневой системы, способствует повышению устойчивости растений при перезимовке, повышает долговечность посевов, дает значительную прибавку урожая. Применение оптимальных доз минеральных удобрений оказывает существенное сдерживающее влияние на фитофагов эспарцета, уменьшая численность и вредоносность главнейших вредителей [13].

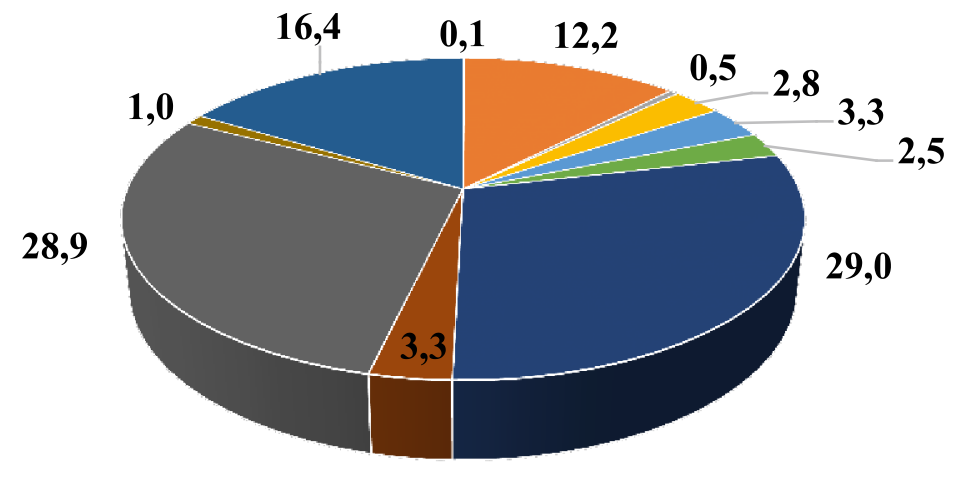

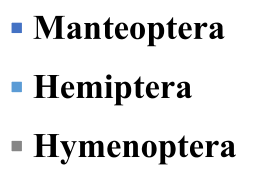

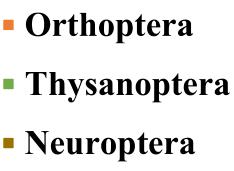

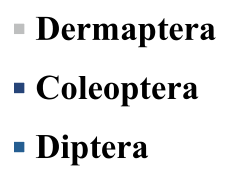

Homoptera

- Lepidoptera

Распределение видов в энтомокомплексе эспарцฺета по отрядам, 2004-2016 22. 
Влияние минеральных и органических удобрений на численность вредителей эспарцета (фаза стеблевания), среднее за 2004-2016 гг.

\begin{tabular}{|c|c|c|c|c|c|c|}
\hline \multirow[t]{3}{*}{ Вариант } & \multicolumn{6}{|c|}{ Численность фитофагов, экз/м² } \\
\hline & \multicolumn{2}{|c|}{$\begin{array}{c}\text { клубеньковые } \\
\text { долгоносики }\end{array}$} & \multicolumn{2}{|c|}{$\begin{array}{c}\text { листовой люцерновый } \\
\text { долгоносик }\end{array}$} & \multicolumn{2}{|c|}{ люцерновый клоп } \\
\hline & \begin{tabular}{|c|} 
предпосевная \\
обработка \\
бишофитом \\
\end{tabular} & \begin{tabular}{|c|} 
без об- \\
работки би- \\
шофитом
\end{tabular} & $\begin{array}{c}\text { предпосевная } \\
\text { обработка } \\
\text { бишофитом } \\
\end{array}$ & \begin{tabular}{|c|} 
без об- \\
работки \\
бишофитом \\
\end{tabular} & \begin{tabular}{|c|} 
предпосевная \\
обработка \\
бишофитом \\
\end{tabular} & $\begin{array}{c}\text { без об- } \\
\text { работки } \\
\text { бишофитом } \\
\end{array}$ \\
\hline \multicolumn{7}{|c|}{ Посевы второго года жизни } \\
\hline Контроль & 0,82 & 1,83 & 0,67 & 1,62 & 0,34 & 0,68 \\
\hline $\mathrm{N}_{30} \mathrm{P}_{90} \mathrm{~K}_{70}+\mathrm{N}_{100}$ & 0,31 & 0,68 & 0,24 & 0,82 & 0,15 & 0,30 \\
\hline Сидерат, 20 т/га & 0,3 & 0,71 & 0,31 & 1,13 & 0,15 & 0,23 \\
\hline Солома, 6 т/га $+\mathrm{N}_{60}$ & 0,24 & 0,52 & 0,44 & 0,96 & 0,18 & 0,31 \\
\hline Навоз, 60 т/га & 0,29 & 0,63 & 0,48 & 1,01 & 0,20 & 0,28 \\
\hline $\mathrm{HCP}_{05}(\mathrm{AB})$ & \multicolumn{2}{|c|}{0,41} & \multicolumn{2}{|l|}{0,15} & \multicolumn{2}{|c|}{0,13} \\
\hline \multicolumn{7}{|c|}{ Посевы третьего года жизни } \\
\hline Контроль & 2,96 & 4,36 & 1,42 & 2,94 & 2,31 & 3,58 \\
\hline $\mathrm{N}_{30} \mathrm{P}_{90} \mathrm{~K}_{70}+\mathrm{N}_{100}$ & 1,42 & 3,24 & 0,87 & 1,92 & 1,61 & 2,49 \\
\hline Сидерат, 20 т/га & 1,56 & 3,01 & 0,94 & 2,02 & 1,42 & 2,30 \\
\hline Солома, 6 т/га $+\mathrm{N}_{60}$ & 1,63 & 3,74 & 0,98 & 1,78 & 1,47 & 2,43 \\
\hline Навоз, 60 т/га & 1,54 & 3,28 & 1,01 & 1,53 & 1,38 & 2,35 \\
\hline $\mathrm{HCP}_{05}(\mathrm{AB})$ & \multicolumn{2}{|c|}{0,58} & \multicolumn{2}{|c|}{0,38} & \multicolumn{2}{|c|}{0,64} \\
\hline
\end{tabular}

Из макроэлементов важнейшую роль в снижении ущерба от фитофагов играет фосфор. Воздействие фосфора на насекомых происходит опосредованно и связано с некоторыми особенностями действия этого элемента на растения эспарцета. Внесение фосфорно-калийных удобрений сдвигает баланс обменных реакций в растении в сторону синтеза высокомолекулярных органических соединений, при этом снижается обводненность клеток и доступность корма для фитофагов уменьшается [13].

Рассматривая роль органических удобрений в регулировании численности и вредоносности фитофагов, П.В. Писаренко и С.В. Пономаренко [14] указывают, что внесение сидератов в рамках органической системы земледелия положительно сказывается на снижении численности вредителей и возрастании количества жужелиц.

В наших исследованиях дана оценка изменения численности фитофагов под воздействием различных агрохимических фонов и предпосевной обработки семян эспарцета песчаного бишофитом в условиях орошения. Результаты изучения влияния минеральных и органических удобрений на плотность вредителей эспарцета второго и третьего лет жизни в фазу стеблевания представлены в таблице.
На основании проведенных исследований нами установлена зависимость численности вредителей эспарцета от применения различных доз минеральных и органических удобрений, а также положительное воздействие предпосевной обработки семян эспарцета бишофитом на снижение плотности фитофагов.

Результаты, представленные в таблице, показывают, что применение минеральных и органических удобрений в сравнении с контролем (без применения удобрений) во всех случаях способствовало достоверному снижению численности вредителей на посевах второго и третьего лет жизни эспарцета в орошаемых условиях. Так, численность имаго клубеньковых долгоносиков снижалась с 0,82-1,83 экз/м² на посевах второго года жизни без применения удобрений до 0,24-0,71 экз/ $\mathrm{M}^{2}$ на вариантах с внесением минеральных и органических удобрений, на посевах третьего года

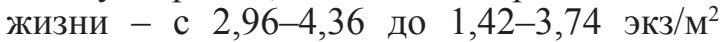
соответственно. Численность люцернового фитономуса - одного из опасных вредителей многолетних бобовых трав, снижалась с 0,67-1,62 на контроле второго года жизни до 0,24-1,13 экз/ $\mathrm{M}^{2}$ на различных агрохимических фонах. Посевы эспарцета третьего года жизни накапливали вредите- 
ля в большей степени, но также наблюдалось сокращение численности фитофага с 1,42-2,94 на контроле до 0,87-2,02 экз/ $\mathrm{M}^{2}$ на агрохимических фонах. Численность люцернового клопа без применения удобрений составляла во второй год жизни 0,34-0,68, в третий год - 2,31-3,58 экз/ $\mathbf{M}^{2}$, а при внесении удобрений снижалась соответственно до $0,15-0,31$ и 1,38-2,49 экз/м². Сокращение численности фитофагов фитояруса в вариантах с расчетными нормами минеральных удобрений и различными видами органических удобрений объясняется тем, что при улучшении питания формируются растения с более мощным габитусом, стенки клеток эпителия утолщаются, что приводит к снижению доступности растений для потребления вредителями.

Сравнивая между собой варианты с применением минеральных и органических удобрений, отметим, что не выявлено достоверных различий снижения численности клубеньковых долгоносиков, листового люцернового долгоносика и люцернового клопа по вариантам применения как расчетных доз минеральных удобрений, так и различных видов органических удобрений. Хотелось бы отметить также, что в научной литературе недостаточно сведений о влиянии органических удобрений на фитофагов фитояруса, хотя есть интересные работы по оценке влияния систем органических, минеральных удобрений и фитомассы растительных сидератов на почвенную мезо- и макрофауну [15].

По нашим данным, обработка семян эспарцета бишофитом оказала сдерживающее влияние на численность всех изучаемых видов фитофагов как на посевах второго, так и третьего лет жизни. Установлено, что применение бишофита снизило численность ситонов на посевах второго года жизни на 55,1-57,7\%, на посевах третьего года жизни - на 32,1-56,4\%. Снижение численного обилия листового люцернового долгоносика составило соответственно $52,4-58,6$ и 34,0-54,6\%, а люцернового клопа $-28,5-50,0$ и 35,3-41,2\%.

\section{Заключение}

Исследованиями установлено, что в энтомоценоз эспарцета входит 875 видов, в числе которых 387 видов фитофагов. Наиболее многочисленными в энтомокомплексе эспарцета в Нижнем Поволжье являются представители отрядов Coleoptera и Hymenoptera (29,0 и 28,9\% от общего числа видов).
Среди фитофагов фитояруса отмечены как многоядные, так и специализированные виды. Периодически эспарцету наносят серьезные повреждения полифаги: луговой мотылек (Loxostege sticticalis L.), люцерновая (Heliothis viriplaca Hfn.) и хлопковая (Helicoverpa armigera Hbn.) совки, медведка обыкновенная (Gryllotalpa gryllotalpa L.), личинки щелкунов и чернотелок (сем. Elateridae и Tenebrionidae) и др. Из олигофагов значительны повреждения листовым люцерновым долгоносиком (Hypera postica Gyll.), жуками и личинками различных видов клубеньковых долгоносиков (Sitona spp.), имаго и личинками люцернового клопа (Adelphocoris lineolatus Goeze.) и гороховой тлей (Acyrthosiphon pisum Harris.).

Наиболее многочисленными энтомофагами герпетобия являются представители семейства жужелиц, их зарегистрировано 78 видов. В фитоярусе эспарцета зарегистрированы хищные клопы из родов Nabis и Orius, хищные трипсы (Thrips spp.), жуки и личинки из семейства Coccinellidae. В травостое эспарцета отмечены также имаго перепончатокрылых из семейств Ichneumonidae, Pteromalidae, Tetrastichidae, Scelionidae.

Исследования показывают, что применение минеральных и органических удобрений на посевах эспарцета в сравнении с контролем (без применения удобрений) во всех случаях способствует достоверному снижению численности вредителей на посевах второго и третьего лет жизни эспарцета в орошаемых условиях. Установлено, что обработка семян эспарцета бишофитом оказала сдерживающее влияние на численность всех изучаемых видов фитофагов, снижение численности вредителей при применении бишофита составило от 28,5 до 58,6\% на посевах второго и третьего лет жизни.

\section{Список литературы / References}

1. Игнатьев С.А., Регидин А.А. Результативность селекции эспарцета на кормовую и семенную продуктивность // Зерновое хозяйство России. 2018. № 3 (57). С. 49-52. DOI: 10.31367/2079-8725-2018-57-3-49-52.

Ignat'ev S.A., Regidin A.A. The effectiveness of breeding sainfoin on feed and seed productivity // Zernovoe hozjajstvo Rossii. 2018. № 3 (57). P. 49-52 (in Russian).

2. Sheppard S.C., Cattani D.J., Ominski K.H., Biligetu B. Sainfoin production in western Canada: A review of agronomic potential and environmental benefits. Grass and Forage Science. 2019. Vol. 74. Iss. 1. P. 6-18. DOI: 10.1111/gfs.12403.

3. Гасиев В.И., Бекузарова С.А., Калоев Б.С., Осикина Р.В. Продуктивность эспарцета в зависимости от норм и способов посева // Известия Горского государственного аграрного университета. 2017. Т. 54. № 2. С. 37-42.

Gasiev V.I., Bekuzarova S.A., Kaloev B.S., Osikina R.V. The productivity of sainfoin depending on the norms and methods of seeding // Izvestija Gorskogo gosudarstvennogo agrarnogo universiteta. 2017. T. 54. № 2. P. 37-42 (in Russian). 
4. Золотарев В.Н., Переправо Н.И. Состояние травосеяния и перспективы развития семеноводства многолетних трав в России и Нижневолжском регионе // Известия Нижневолжского агроуниверситетского комплекса: наука и высшее профессиональное образование. 2016. № 1 (41). С. 93-101.

Zolotarev V.N., Perepravo N.I. The state of grass sowing and the prospects for the development of perennial grass seed production in Russia and the Lower Volga region // Izvestija Nizhnevolzhskogo agrouniversitetskogo kompleksa: nauka i vysshee professional'noe obrazovanie. 2016. № 1 (41). P. $93-$ 101 (in Russian).

5. Morril W.L., Ditterline R.L., Cash S.D. Insect pests and associated root pathogens of sainfoin in western USA. Field Crops Research. 1998. Vol. 59. Iss. 2. P. 129-134. DOI: 10.1016/ S0378-4290(98)00113-0.

6. Добрынин Н.Д., Прокопчук А.Е. Агротехнические приемы в защите многолетних бобовых трав от вредителей в условиях Юго-Востока ЦЧР // Вестник Воронежского государственного аграрного университета. 2013. № 2 (37) C. $198-205$.

Dobrynin N.D., Prokopchuk A.E. Agrotechnical techniques in the protection of perennial leguminous herbs from pests in the conditions of the South-East Central Black Earth Region // Vestnik Voronezhskogo gosudarstvennogo agrarnogo universiteta 2013. № 2 (37). P. 198-205 (in Russian).

7. Перцева Е.В., Васин В.Г., Перцев С.В. Видовой состав насекомых в смешанных травостоях в лесостепи Самарской области // Известия Самарской государственной сельскохозяйственной академии. 2018. № 3. С. 16-23.

Pertseva E.V., Vasin V.G., Pertsev S.V. Species composition of insects in mixed herbage in the forest-steppe of the Samara region// Izvestija Samarskoj gosudarstvennoj sel'skohozjajstvennoj akademii. 2018. № 3. P. 16-23 (in Russian).

8. Артохин К.С. Метод кошения энтомологическим сачком // Защита и карантин растений. 2010. № 11. С. 45-48.

Artokhin K.S. Method of mowing entomological nets // Zashhita i karantin rastenij. 2010. № 11. P. 45-48 (in Russian).

9. Mykhailenko I.L., Smetana O.M. Method to study soil mesofauna as part consortium ecosystem // Питання біоіндикації та екології. 2014. № 19-1. С. 151-156.

Mykhailenko I.L., Smetana O.M. Method to study soil mesofauna as part consortium ecosystem // Pytannja bioindykacii' ta ekologii'. 2014. № 19-1. P. 151-156 (in Ukrainian).

10. Комаров Е.В., Калюжная Н.С., Черезова Л.Б. Состав и структура сообществ жесткокрылых насекомых (Coleoptera) как показатель состояния степных экосистем Юго-Востока европейской части России // «Степи Северной Евразии: стратегия сохранения природного разнообразия и степного природопользования в XXI веке»: материалы международного симпозиума. 2000. С. 189-190.

Komarov E.V., Kaljuzhnaja N.S., Cherezova L.B. Composition and structure of Coleoptera communities (Coleoptera) as an indicator of the state of steppe ecosystems in the SouthEast of the European part of Russia // «Stepi Severnoj Evrazii: strategija sohranenija prirodnogo raznoobrazija i stepnogo prirodopol'zovanija v XXI veke»: materialy mezhdunarodnogo simpoziuma. 2000. P. 189-190 (in Russian).

11. Комаров Е.В., Комарова О.П. Оптимизация комплексов полезной энтомофауны в орошаемых агроландшафтах Волго-Донского междуречья // Современные проблемы науки и образования. 2016. № 6. [Электронный ресурс]. URL: http://science-education.ru/ru/article/view?id=25990 (дата обращения: 21.08.2020).

Komarov E.V., Komarova O.P. Optimization of useful entomofauna complexes in the irrigated agrolandscapes of VolgaDon interfluve // Sovremennye problemy nauki i obrazovanija. 2016. № 6. [Electronic resource]. URL: http://science-education.ru/ru/article/view?id=25990 (date of access: 21.08.2020) (in Russian).

12. Прокопчук А.Е., Добрынин Н.Д. Роль минеральных удобрений в регуляции численности вредной энтомофауны на семенных посевах многолетних бобовых трав // Политематический сетевой электронный журнал Кубанского государственного аграрного университета. 2014. № 95. С. 215231. [Электронный ресурс]. URL: https://rus.neicon.ru/xmlui/ handle/123456789/17258 (дата обращения: 21.08.2020).

Prokopchuk A.E., Dobrynin N.D. The role of mineral fertilizers in the regulation of the number of harmful entomofauna in the seed crops of perennial legumes // Politematicheskij setevoj elektronnyj zhurnal Kubanskogo gosudarstvennogo agrarnogo universiteta. 2014. № 95. P. 215-231. [Electronic resource]. URL: https://rus.neicon.ru/xmlui/handle/123456789/17258 (date of access: 21.08.2020) (in Russian).

13. Прокопчук А.Е. Энтомофаги вредителей многолетних бобовых трав и регуляция их численности // Вестник Воронежского государственного аграрного университета. 2013. № 4 (39). C. 37-42.

Prokopchuk A.E. Entomophagous of pests of perennial leguminous grasses and regulation of their numbers // Vestnik Voronezhskogo gosudarstvennogo agrarnogo universiteta. 2013. № 4 (39). P. 37-42 (in Russian).

14. Писаренко П.В., Пономаренко С.В. Оптимизация фитосанитарного состояния посевов сельскохозяйственных культур в органическом земледелии // Вестник Курганской ГCXА. 2014. № 3 (11). C. 40-44.

Pisarenko P.V., Ponomarenko S.V. Optimization of the phytosanitary condition of agricultural crops in organic farming // Vestnik Kurganskoj GSHA. 2014. № 3 (11). P. 4044 (in Russian).

15. Витион П.Г. Воздействие различных систем удобрения на динамику численности комплекса педогеобионтов // Агрохимия. 2016. № 9. С. 70-77.

Vition P.G. Effect of various fertilizer systems on the dynamics of the pedogeobiont complex // Agrohimija. 2016. № 9. P. 70-77 (in Russian). 